University of Rhode Island

DigitalCommons@URI

Open Access Master's Theses

1991

\title{
A Study of the Effect of Individual Learning Objective Conferences on Understanding of Self in a Structured Experiential Learning Program at the University of Rhode Island
}

Lynn Gaulin

University of Rhode Island

Follow this and additional works at: https://digitalcommons.uri.edu/theses

\section{Recommended Citation}

Gaulin, Lynn, "A Study of the Effect of Individual Learning Objective Conferences on Understanding of Self in a Structured Experiential Learning Program at the University of Rhode Island" (1991). Open Access Master's Theses. Paper 1565.

https://digitalcommons.uri.edu/theses/1565

This Thesis is brought to you for free and open access by DigitalCommons@URI. It has been accepted for inclusion in Open Access Master's Theses by an authorized administrator of DigitalCommons@URI. For more information, please contact digitalcommons-group@uri.edu. 
A STUDY OF THE EFFECT OF INDIVIDUAL LEARNING OBJECTIVE CONFERENCES ON UNDERSTANDING OF SELF IN A STRUCTURED EXPERIENTIAL LEARNING PROGRAM AT THE UNIVERSITY OF RHODE ISLAND BY LYNN GAULIN

A THESIS SUBMITTED IN PARTIAL FULFILLMENT OF THE REQUIREMENTS FOR THE DEGREE OF MASTER OF ART IN ADULT EDUCATION 


\section{ABSTRACT}

The purpose of this study was to determine if undergraduate students who participated in objective setting conferences prior to a full-time internship exhibited greater self-awareness than students who did not. Using a Solomon 4 group design and the $t$ test for independent samples, it was found there was no significant statistical difference between the experimental and control group. A conclusion drawn from the study was that although objective setting conferences may not lead to greater self awareness on a standardized inventory, individual conferences help students become focused and actively engaged in the learning experience. 
ACKNOWLEDGMENTS

University of Rhode Island students who have an interest in stretching their educational experience through their participation in the University Year for Action Intern Program made this study possible. Also, I thank Richard Sullivan for the many conversations over the years about experiential education and introducing me to the work of David Kolb and the concept of reflectivity in an experiential education program. 
Page

ABSTRACT

ACKNOWLEDGMENTS

i i i

LIST OF TABLES ...................... v

LIST OF FIGURES ..................... vi vi

1. INTRODUCTION ....................... 1

STATEMENT OF THE PROBLEM ............. 4

REVIEW OF LITERATURE ................ 4

STATEMENT OF HYPOTHESIS ............... 10

DEFINITION OF TERMS ................. 11

2. METHODOLOGY ........................ 14

POPULATION AND SAMPLE ............... 14

INSTRUMENTATION ..................... 15

EXPERIMENTAL DESIGN ................. 17

DATA COLLECTION ................... 18

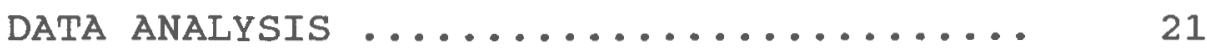

3. RESULTS .......................... 22

DISCUSSION OF FINDINGS .............. 25

4. SUMMARY, CONCLUSION AND RECOMMENDATIONS.... 28

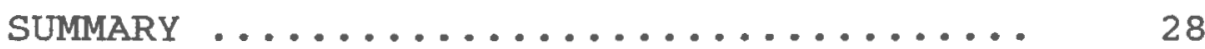

CONCLUSION ....................... 29

RECOMMENDATIONS ................... 32

APPENDIX $\ldots \ldots \ldots \ldots \ldots \ldots \ldots \ldots \ldots \ldots \ldots \ldots \ldots \ldots \ldots \ldots . \ldots \ldots$

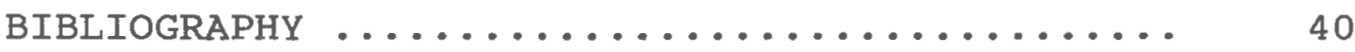


Table Page

Table 1: Unpaired t-Test Between Pretest

Experimental and Control Groups ....... 22

Table 2: Pretest and Posttest Means, Standard

Deviations and $t$-Tests of students in

the Experimental and Control Groups .... 23

Table 3: One Factor Analysis of Variance of the Posttest Means, Standard Deviations and F Test for 4 Groups ................. 23

Table 4: Means, Standard Deviations and t-Tests for Independent Sample .............. 25

Table 5: A Comparison of Some Individual Pre and Post Test Scores of Students Assigned to the Experimental and Control Groups ....... 27 


\section{LIST OF FIGURES}

Figure

Page

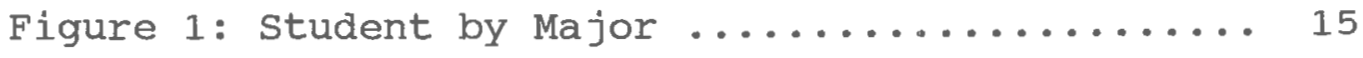

Figure 2: Group Assignment ................ 17 
CHAPTER 1

INTRODUCTION

Educators involved in undergraduate experiential learning programs such as the University Year for Action (UYA) Intern Program at the University of Rhode Island are challenged to assess and measure the knowledge and skills that students acquire in a nontraditional learning environment. Unlike the traditional classroom where examinations on course content are given and a measurement of learning can be administered, measuring achievement and defining success in an experience-based learning program has been based primarily on descriptive research and anecdotal information. Measurement of accomplishment in the form of grades is not the norm for most experiential programs. Many programs, including the UYA Intern Program assign a pass/fail grade at the end of the semester. How does a student, with a pass/fail grade, make a determination about her/his accomplishments and skills after participating in an experiential learning program? Does the student perceive him/herself as competent after such an experience? How aware is a student about the changes to self that may result from an internship?

Edward cell (1984) notes that more effective learning from experience takes place when one is clearly aware of both the behavioral changes that have occurred and the 
accomplishments that led to the change. Cell states, "our effectiveness in learning from experience will involve how we prepare, the conditions we encounter and how we later assess or otherwise reflect on what we've learned" (p.54). Learning theorists suggest four aspects of self influence learning with self concept as the single most significant organizer of making sense out of an experience (McCarthy \& Schmeck, 1988). Human relation trainers consider that heightened awareness of one's individualistic style of interacting to be a major outcome of a structured learning experience (University Associates 1990). Other trainers in discussing interpersonal perception note that failure to perceive accurately can lead one to miss important messages that others transmit (Gazda, Asbury, Balzer, Childers \& Walters, 1977).

Malcolm knowles (1976) suggests that an important task for the adult learner is learning how to take responsibility for her/his learning by analyzing one's own experience. Knowles emphasizes the need for adults to participate to defining the learning experience based on the assumption that "the more active the learner's role in the process, the more he is probably learning" (p.45).

The learning contract is one method that many experiential educational programs use to guide, and involve 
the student in defining the learning experience. The learning contract process often includes the development of learning objectives by the student prior to the internship. Learning contracts that spell out the expected acquisition of skills and knowledge are one method that allows the student to "look at themselves more objectively and free their minds from preconceptions" (p.45), what Knowles labels "an unfreezing experience" (p.45).

Review of the literature on experiential education indicates that specified learning objectives set by the learner lead to more effective learning. How seriously and carefully do students frame learning objectives? Is it sufficient to require students to develop learning objectives with written guidelines prior to an internship or should time be spent with individual students in discussing the framing of learning objectives that will reflect not only skill attainment but also personal development and identifying possible behavior change? will development of learning objectives based on learning needs enhance the student's reflective process that leads to greater understanding of self. One study can not answer all the above questions, but studying the effect of time and consultation with individual students during the preparation stage for the internship experience may begin to provide some answers. 
STATEMENT OF THE PROBLEM

The purpose of this study was to determine the effect of individual student objective setting conferences on the student's perception of self after participating in a structured internship program. The use of the terms experiential learning and internship are interchangeable throughout this study. Internship is defined as a structured experience where a framework is developed to provide undergraduate students an opportunity to learn by taking on responsibility in a work setting and identify, observe and reflect on the changes that occur as a result of the experience. (Stanton, 1982)

REVIEW OF SELECTED LITERATURE

We learn through multiple experiences in our daily living. In the structured internship programs, students are expected to apply academic learning in a work setting. In addition, it is anticipated that students will develop skills and gain further knowledge, along with experiencing change behaviorally, further develop personally and become exposed to management styles and various roles encountered in the workplace (Permaul, 1982). Investigation into the question of how and what we learn from experience suggests that experience turns into learning when: 1. preparation for the experience takes place; 2 . the student engages in 
the activities, and 3. a process and framework is developed that emphasizes reflectivity (Boud, Keogh, \& Walker, 1985; Cell, 1984; Ross, 1989; Schon, 1987; Smyth, 1989; Sugarman, 1985). Candy, Harri-Augstein, and Thomas (1983) suggest that if people's awareness of what is happening to them can be heightened, and if they can intentionally examine life events, then they can make more of each experience. This can apply to a new job, reading a book or attending a lecture. Schon (1987) in his study of reflectivity practices in the training of students in professional schools, describes learning new competencies as a paradox " a student cannot at first understand what he needs to learn, can learn only by educating himself and can educate himself only by beginning to do what he does not yet understand." (p.93)

Proponents of cognitive-structural developmental theory assert that only when experience can be expressed as new ideas, when lessons of experience are articulated and acted upon, can development take place (Whitman \& Erdynast, 1982). Mentkowski and Doherty (1983) further suggest that "the mere act of identifying outcomes and giving people a chance to practice them has a powerful impact that carries from college to later life." (p. 107). Kolb (1984), however, cautions that the simple perception of experience does not necessarily lead to learning; for Kolb, learning occurs when the experience is transformed with action. Boud, Keogh and 
Walker (1985), in their discussion of what turns learning into experience, view the reflective process as one complicated by feelings and cognition and believe this complexity must be taken into account when working with students. In addition, they identify the reflective process as one that is too often overlooked in formal learning settings including experiential education programs.

A strategy used by many sponsored experiential learning programs is the development of a learning contract prior to the beginning of the experience. This learning contract actively involves the student in the design of the experience including developing learning objectives. Arner (1979) views the use of contracts as allowing the student learners to engage in creative and personally relevant learning activities. With clearly identified goals, students have a sense of direction and purpose for their learning. The process of thinking through objectives prior to an experience allows an individual to become more aware of the possible changes and the learning that may take place. Having the student actively involved in developing a learning contract, Knowles (1986) believes, assists the student in 'diagnosing' learning needs. Cell (1984) agrees that the effectiveness in learning from experience is determined by how the preparation is done, the conditions encountered and how one processes the experience.

A review of the learning objectives developed by 
University Year for Action (UYA) student interns (1989-90 academic year) at the University of Rhode Island as part of the learning contract prior to the internship semester, fell into two major categories - cognitive development and personal development (see glossary for operating definitions of cognitive and personal development). Objectives reflecting the cognitive aspect typically stated "learn how to apply my major to specific tasks of the organization", "gain understanding of the judicial system", "perform basic and complex functioning tasks in agency", "gain knowledge of the types of therapy available in aiding individuals towards recovery". Some objectives were job specific such as "learn skills for working on a computer", "establish a resource center that may be used by anyone needing information on women's issues in Rhode Island". Personal development objectives included statements such as "further develop my own person through this experience", "develop professional skills to communicate successfully with managers, supervisors and peers ...", " learn how to develop professional relationships with client populations." Only an occasional objective was found that indicated the student had identified a behavior or feeling he /she was willing to change such as "gain confidence in my abilities". In Permaul's (1982) discussion of learning objectives for personal development, Permaul contends that an element of self knowledge is an acknowledgement of a willingness to 
change.

Candy, Harri-Augstein, and Thomas (1985) believe that "much potentially valuable learning is 'lost' because learners have not developed the skills of recreating or reliving learning which they experience" (p.114). They further suggest that 'learning conversations' can be "a form of dialogue about a learning experience in which the learner reflects on some event or activity in the past".'Learning conversations', they asset, offer students an opportunity to engage in critical self-awareness through the prompting, probing and inquiry and call for the development of new tools and procedures for developing learning-to-learn skills.

In exploring the research conducted on experiential education, David Moore (1984) concludes that too much research has been descriptive and too little research has been done on the processes of interventions. He calls for more developmental studies on cognitive, emotional and social dimensions and more research on the various pedagogical strategies employed by experiential education programs.

A review of the literature has not uncovered any current research on the effect of individual conferences for objective setting in relation to increased self-awareness by the learner in an experiential learning situation. While research does indicate the greater degree of student 
involvement in their education, the more likely they are to learn (Cone, 1985), isolation of the contributing factors that lead to greater understanding of what is learned by the learner can offer new insights for the experiential educator.

Candy, Harri-Augstein, and Thomas (1985) assert that reflective learning occurs, not through solitary contemplation but often as a result of talking about ideas or an experience with another person. However, given the fact that undergraduate students may have few opportunities to 1. participate in 'learning conversations' 2 . shape and define a learning experience or 3. develop learning objectives, perhaps 'learning conversations' could start when the student begins developing learning objectives for the learning contract.

All students participating in the UYA Intern Program are required to submit a completed learning contract before the internship begins. Students are given guidelines in the UYA Intern Handbook (1990) on developing and completing the learning contract. The learning contract consists of three components, the student's learning objectives, an agency job description and the academic description. The students are advised in the handbook that developing learning objectives in terms of the specific skills, knowledge and attitudes that the student wants to receive from the internship is the "single most important component of the planning process" 
(p.6). It is further suggested in the handbook that students consider developing objectives focusing on career awareness, professional development and human relations.

STATEMENT OF THE HYPOTHESIS

Research findings suggest that student initiated objectives lead to greater learning (Boud, Keogh, Walker, 1985; Knowles 1970, 1986; Loacker \& Doherty, 1984; Mentkowski \& Doherty 1983; Permaul, 1982; University Associates, 1990). It is further suggested by Candy (1985) that in order to facilitate greater understanding by the learner of an experience, the use of specific techniques to foster reflective learning is effective in promoting selforganized learning. During the development of a learning contract, with written objectives, there is an opportunity for the educator and learner to come together for a 'learning conversation'. All students in this sample wrote a learning contract.

Therefore, it was hypothesized that individual student conferences on objective setting for students enrolled in a sponsored experiential learning program would lead to greater self-awareness than for students who did not participate in individual conferences. 
DEFINITION OF TERMS

Cognitive development: learning theories based on the work of Piaget and more recently Kolb, that consider learning as a process occurring from infancy through adulthood in identifiable stages of concrete experience, active experimentation, reflective observation and abstract conceptualization.

Experiential education: an educational activity that engages the student in the learning process outside of the traditional classroom with emphasis on the changes that occur as a result of the experience.

Learning contract: a document that formally establishes the relationship among the student intern, the sponsoring organization and the faculty advisor.

Learning conversation: a process for learning, as discussed by Candy, Harri-Augstein, and Thomas (1985), that includes, in the beginning stages, a dialogue between learner and teacher that focuses on a learning experience in which the learner reflects on the past event and activity.

Learning objective: a statement that specifies a desired learning outcome in terms of skill attainment, knowledge, attitude and behavior.

Nontraditional learning environment: a setting, outside of the traditional classroom, where students have an opportunity to apply knowledge, develop skills and learn 
from experience.

Personal development: the belief that individuals pass through stages from birth to old age and that the stages "are further subdivided according to physical, cognitive, emotional, social and moral development." (Encyclopedia of Social Work, p. 244)

Self-awareness: understanding and insight into one's behavior, development and changes that occur as the result of an experience.

Self-concept: a relatively consistent, organized perception a person holds of him or herself. (Wood,1988; Rogers as discussed by Zastrow \& Kirst-Ashman, 1990)

Self-perception: the person that one believes themselves to be, formed in part from critical interactions with other persons that are important to self. (Soares, 1985; Wood, 1988)

UYA Intern Handbook: a handbook given to accepted students in the UYA Program that outlines the necessary steps in securing a full-time internship.

University Year for Action Intern Program: an university wide, academic program at The University of Rhode Island for students who have earned at least sixty credits (Junior or Senior standing), have a minimum grade point average of 2.5 and have the willingness and flexibility to use fifteen elective credits learning in a professional setting for four days a week totalling thirty-two hours and 12 
attending a weekly seminar. 
CHAPTER 2

METHODOLOGY

POPULATION AND SAMPLE

Subjects for this study were University of Rhode Island undergraduate juniors and seniors who enrolled in the fulltime (32 hours per week) internship program for fifteen (15) credits, met the eligibility requirements of a $2.5 \mathrm{GPA}$ and had at least sixty credits. Over 100 students participate each year in the internship program. At the time when this study was proposed, it was estimated that forty (40) students would participate in the UYA Program during the Spring semester of 1991 and would be the sample for the study. Over sixty (60) students completed the application process, were accepted for the spring semester and given the UYA Intern Handbook. Fifty-six students finalized an internship placement after having a series of interviews with potential site supervisors. Fifty-three (53) students (10 -males, 43 - females) completed learning contracts.

Students enrolled in the internship program represent a cross-section of disciplines (see figure 1) with the exception of the nursing, pharmacy, fashion merchandising and physical education programs. No engineering undergraduate students applied for the Spring, 1991 semester. Students completing internships in out-of-state 
placements and students repeating the UYA Intern Program were not included in the sample since their internship experience did not include the weekly UYA seminar. Two students who were known to the investigator to be roommates were eliminated since random assignment could lead to possible contamination. A replacement pool of 10 students was established.

Figure 1

\section{Student By Major}

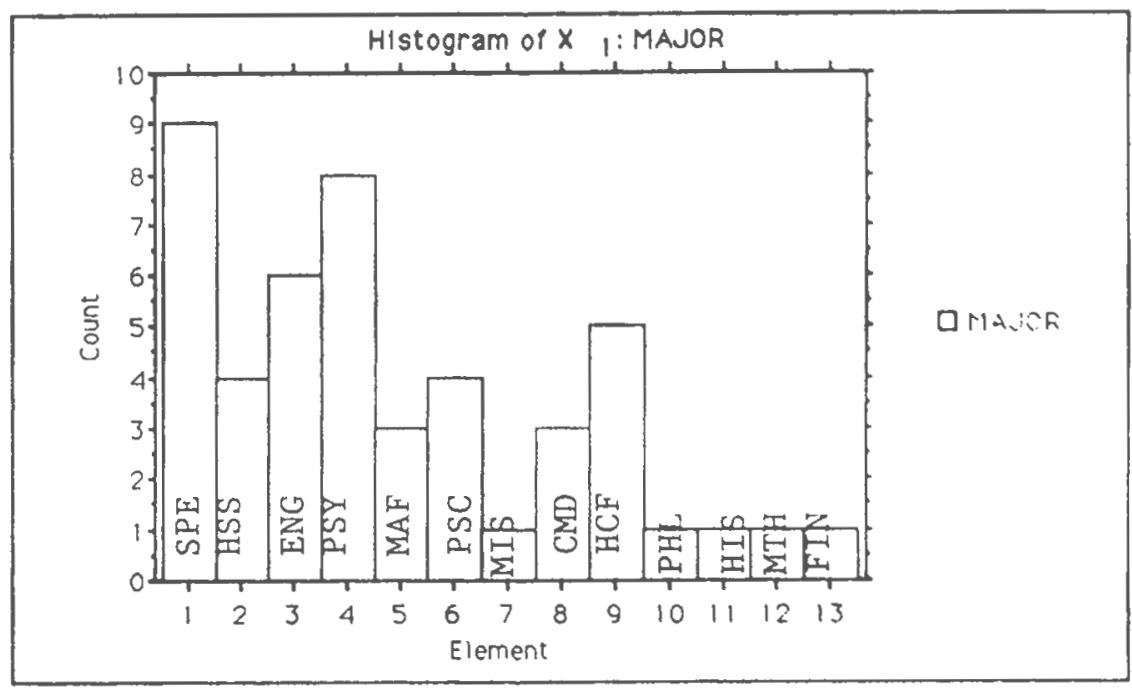

The students in this study represent undergraduate students at the junior and senior level enrolled in an experiential learning program and not the general undergraduate population enrolled in traditional classes. Four students were non-traditional age (over 30 years of age).

\section{INSTRUMENTATION}

The Student Self Inventory, Adult form of Soares Self- 
Perception Inventory, was the instrument for this study. This instrument measured the subject's perception of self as a student. The thirty items on the inventory include adjectives such as competent versus incompetent, confident versus insecure, reliable versus unreliable. The scores range from -60 to +60 ; according to Soares ((1985) a score falling between the fourth and sixth stanine indicates a positive perception of self.

The test-retest reliability is reported quite high $(r=.88)$ and while evidence of validity is reported by the reviewer as incomplete, the reported data are fairly convincing. Riggs (1985), in her review, reports that "correlations between student teachers" ratings of selfconcepts as teachers and ratings of internship competence (.37) and ratings of on the job success (.38) support the predictive validity of the teacher form" ( $p .1351$ ). Correlations between SPI and Coopersmith's Self-Esteem Inventory (.29 to .68) attest to the validity of the student form according to Riggs. Riggs, however, expressed concern of the problem of multiple form inventories, particularly the effect that one's response on one form might have on subsequent forms. The reviewer, however, concluded that the SPI is an unique inventory that provides assessment of self from a variety of perspectives but cautions the inventory not be used for clinical judgments but confined to research settings. 
EXPERIMENTAL DESIGN

The design selected for this study is the solomon FourGroup Design (see figure 2). This design was selected because the study was relatively short in duration (three months), the group size was expected to stay constant, and controls were needed for pretest-treatment interaction. Students in this study self-selected to be in the UYA Intern Program but random assignment to groups was possible by the flip of a coin. The threat to internal validity of differential selection of subjects by using students enrolled in the experiential learning program was controlled by random assignment of all students, regardless of age or gender, to groups. Little difference among groups was anticipated since the students in the study met the program requirements, had junior or senior standing and applied for the program voluntarily. 


\section{Figure 2}

Group Assignment

\begin{tabular}{|c|l|c|l|c|c|}
\hline $\begin{array}{l}\mathrm{G} \\
\mathrm{u} \\
\mathrm{u}\end{array}$ & Assignment & Number & Treatment & Pre-test & Posttest \\
\hline 1 & random & 9 & $\begin{array}{l}\text { handbook } \\
\text { instructions } \\
\text { only }\end{array}$ & ss & ss \\
\hline 2 & random & 8 & $\begin{array}{l}\text { individual } \\
\text { learning } \\
\text { objective } \\
\text { conference }\end{array}$ & ss & ss \\
\hline 3 & random & 19 & $\begin{array}{l}\text { handbook } \\
\text { instructions } \\
\text { only }\end{array}$ & no & ss \\
\hline 4 & random & 10 & $\begin{array}{l}\text { individual } \\
\text { learning } \\
\text { objective } \\
\text { conference }\end{array}$ & no & ss \\
\hline
\end{tabular}

DATA COLLECTION

Students assigned to groups 1 and 2 were asked to complete the Soares student self perception inventory on an scheduled day 10 weeks prior to the start of the internship. Because four staff members were advising students about internships for the spring semester and in order to control the instructions and information given to students regarding the completion of their learning contracts, all students were instructed to schedule a 
meeting with the investigator regarding their learning contracts. All students scheduled and attended the meetings .

During these scheduled meetings, all students were given the necessary information to complete the learning contract in terms of the three components of learning objectives, agency description and academic description. Discussions with students assigned to the experimental group 2 and 4 centered on developing attitudinal and behavioral objections, skill acquisition objectives and career related objectives. Students were encouraged to articulate their objectives and encouraged to make notes during the discussion to use as a basis for writing their final learning objectives.

During the meeting, students were asked to: 1 . diagnose their learning needs, 2. consider objectives describing what they will learn, 3. develop strategies on how they planned to accomplish their objectives and 4 . identify areas that would help them determine whether or not they learned what they set out to learn. At the end of the meeting, students were given a handout describing steps for developing learning objectives, a worksheet and examples of the completed objectives (see Appendix A, B, \& C).

The control group, $1 \& 3$, received the written instructions contained in the UYA Intern Handbook. No 
additional information or explanation was given on developing learning objectives. If a student specifically asked about learning objectives, the information contained in the handbook was reviewed with the student.

Two students, one in group 1 and one in group 2, withdrew from the internship program the beginning week of the internship. Another student in group 2 withdrew after three weeks into the internship semester, leaving 18 students in the experimental group and overall 47 students included in the study including the replacement pool.

Because of the number of students enrolled for the UYA internship, two seminar classes were established. There was no difference in the assignments given to the students in the two seminars. Assignments included journal writing, short papers, resume writing and class discussion. At the beginning of the semester, students were encouraged to meet individually with staff on the areas of concern to the student but were not assigned individual conference times.

During the eighth week of the internship, all students were given the Soares student self perception inventory. students also completed a narrative evaluation of their experience. At the end of the internship semester, students completed a final evaluation that included among the eight items, a rating for the accomplishment of learning objectives. Students were asked to rate the items on a 
scale of 1 to $5,(1=$ poor, $2=$ below expectations, 3=acceptable, 4=above expectations, 5=excellent). At this seminar meeting, students were given results on the group data from the Soares student self inventory.

Supervisors were not asked to complete a supervisor perception of student subtest because of the anticipated difficulty of collecting the data from placements sites scattered throughout the state in a timely manner. Because of the short duration of the study, it was decided not to use a blended methodology that included case studies.

\section{DATA ANALYSIS}

A $t$ test was used to determine if the means of the experimental and control group pretest and posttest scores were significantly different. The t-test was selected as an appropriate statistical test because the groups were randomly formed. An alpha level of $\mathrm{p}<.05$ was used to determine significance. An unpaired $t$ test was also used to confirm that there was no statistical difference between the pretest groups. 


\section{CHAPTER 3}

\section{RESULTS}

The null hypothesis states there would be no significant difference between the posttest scores of the Soares student self perception inventory of students participating in the objective setting conferences than students who did not participate in individual conferences.

Examination on the results of the unpaired $t$ test of the pretest means indicate the groups were equivalent prior to the experiment; no statistical difference between the two groups was demonstrated (see Table 1).

Table 1

Unpaired $t$-Test Between Pretest Experimental and Control Groups

\begin{tabular}{|c|l|l|l|l|l|}
\hline Group & $\mathrm{N}$ & $\underline{\mathrm{M}}$ & $\mathrm{sd}$. & $\mathrm{df}$ & $t$ \\
\hline Pretest Experiment & 8 & 38.4 & 11.9 & 15 & $.1 *$ \\
\hline Pretest Control & 9 & 37.8 & 12.6 & & \\
\hline
\end{tabular}

$\underline{p}>.05$

* Not statistically significant

Examination of the pretest and posttest means on the Soares Student Self Inventory and t-test results, for dependent sample, showed no significant difference between the groups (see Table 2). 
Table 2

Pretest and Posttest Means, Standard Deviations and t-Tests of students in the Experimental and Control Groups.

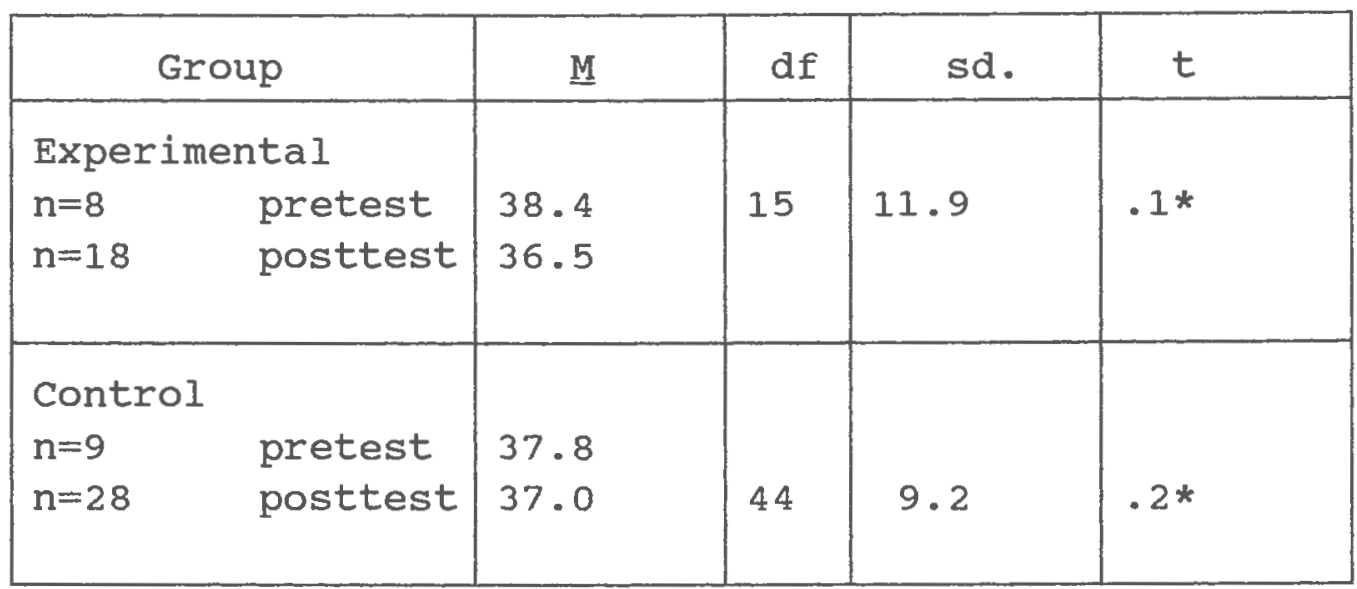

*Not statistically significant p $>.05$

The posttest means of the four groups were analyzed by a one factor analysis of variance and the $F$ test showed no significant difference among the groups (see Table 3).

Table 3

one Factor Analysis of Variance of Posttest Means and Standard Deviations for Four Groups.*

Posttest

\begin{tabular}{|l|c|c|c|}
\hline Group & Number & M & sd. \\
\hline 1 control & 9 & 37.4 & 8.6 \\
\hline 2 experimental & 8 & 39.8 & 9.6 \\
\hline 3 control & 19 & 36.7 & 9.7 \\
\hline 4 experimental & 10 & 33.9 & 9.8 \\
\hline \multirow{2}{*}{$\mathrm{F}_{(3,45)}=.6, \mathrm{p}>.05$} & & \\
\hline
\end{tabular}


After students had completed eight weeks of their internship, the Soares student self Perception Inventory was administered to student interns participating in the UYA Intern Program and attending the weekly seminars. One student in the control group was absent. Results showed no signficant difference between the posttest score of the two groups (see table 4). Therefore, the hypothesis that individual student conferences on objective setting for students enrolled in an experiential learning program would lead to greater self-awareness than for student not participating in individual conferences was not supported. 
Means, Standard Deviations and $t$ Tests for

Independent sample.

\begin{tabular}{|l|l|l|l|l|}
\hline \multicolumn{1}{|c|}{ GROUP } & M & df & sd. & t \\
\hline Experimental & 36.5 & 44 & 9.9 & $.2 *$ \\
\hline Control & 37 & & 9.2 & \\
\hline
\end{tabular}

*Not statistically significant

\section{DISCUSSION OF FINDINGS}

Although the results of this study do not support the original hypothesis, understanding how students view themselves before, during and after an internship and understanding the factors that bring about a change in self perception in students, could provide educators important data on developing new strategies and tools for fostering greater awareness of self. Engaging in critical self awareness as discussed by Candy, Harri-Augstein and Thomas (1985), Knowles (1970) and Permaul (1983), suggests that greater learning can take place. Promoting more effective learning, in Cell's (1984) view, includes awareness of the changes in self through understanding the accomplishment(s) that lead to change. The pre and posttest means in Table 4 suggest that students in this study, as a group, have a positive perception of themselves as students. According to the conversion chart contained in the soares test manual, 
the scores fall in the seventieth percentile suggesting a fairly high group student self concept. This is not a surprising finding since students who participate in the internship program are likely, as a group, to have positive concepts of themselves as students. Potential student interns must meet requirements of a grade point average of 2.5 and have earned at least 60 credits in order to be accepted in the program. The grade point average for the students in this study was 2.88 ; over $90 \%$ of the interns were seniors. There were no observed differences among the students on the basis of age, gender or cultural background.

Although differences between the experimental and control groups and the pretest and posttest groups were not statistically significant, comparing individual pretest scores with the posttest scores (see Table 5), shows that for some student interns, a change in perception of student self takes place. 
TABLE 5

A Comparison of Some Individual Pretest and Posttest Scores of Students Assigned to Experimental and Control Groups •

\begin{tabular}{|c|l|l|c|}
\hline STUDENT & CONF & PRE & POST \\
\hline 1 & no & 34 & 36 \\
\hline 2 & no & 45 & 36 \\
\hline 3 & no & 20 & 32 \\
\hline 4 & no & 41 & 41 \\
\hline 5 & yes & 49 & 48 \\
\hline 6 & yes & 50 & 44 \\
\hline 7 & yes & 51 & 35 \\
\hline 8 & yes & 30 & 53 \\
\hline
\end{tabular}

While it is beyond the scope of this study to analyze individual differences in perception of student self, there appears to be evidence of change in some students. The essence of the change and the factors that influence a change in perception for students participating in an internship are areas for further study. 
CHAPTER 4

SUMMARY, CONCLUSIONS AND RECOMMENDATIONS

SUMMARY

Several inquiries were posed at the beginning of this study: the level of awareness that a student has about his/her accomplishments, the sense of competency, and the overall sense of self as a learner. Cell (1984), Griffin (1983), Stanton (1982) and Knowles (1986) agree that in order for effective learning to take place from experience, the student must actively engage in the process of preparation, in the experiential activity and in reflection about the experience. Student interns in this study, for the most part, were actively involved in these three stages. All students completed a learning contract with learning objectives. The learning objectives developed by the control and experimental groups showed no significant difference from previous semesters. However, some students in the experimental group developed objectives that reflected a learning need articulated during the objective setting conference; some of these objectives were atypical. For example, one student who questioned whether she had the ability to remain objective with clients, developed a learning objective that stated " develop and apply a degree of objectivity to providing service in a professional environment". Another student who had a concern about office 
politics, wrote "relate the routine of office interaction and procedures in a professional setting to previous experiences" •

All students fulfilled the fieldwork and academic requirements of the intern program and most students actively engaged in reflective activities. Some resistance, by some of the students, to participating in self assessment activities during the seminar classes was reported, but review of students' mid-semester evaluations and journals, indicate most students were actively engaged in the reflective process. The hypothesis that students participating in learning objective conferences would have a greater sense of awareness than students not participating in the conferences was not supported. There was no significant difference between the means of the experimental group and the control group.

\section{CONCLUSION}

Although the hypothesis that greater self awareness would be evident if students participated in learning conversations regarding learning objectives was not supported, the importance of careful preparation for an internship that includes careful framing of learning objectives becomes apparent when discussing areas of concern and problems with students during the course of their internship.

During the beginning weeks of the internship semester, 
five (5) students requested individual appointments to discuss problems and concerns regarding the internship. All the students expressed concern about not meeting their learning objectives. One student stated that she had memorized her learning objectives that were to serve as her guide during the internship but she was feeling totally frustrated by the lack of meaningful responsibility and activities. The other students expressed similar concerns and frustrations. Discussions with the students, over a 2-3 week period, centered around strategies and actions that could be taken to assure that their learning objectives could be met. Toward the end of the internship semester, the students who expressed concern about not meeting their learning objectives, were satisfied with the level of responsibility, activity and involvement of their internship placement.

This anecdotal information is included to emphasize the belief that it has been the experience of the UYA Intern Program that most students assume an active role in the learning process. Four out of the five students described, participated in the objective setting conferences where the student played an active role in 'diagnosing' learning needs. That a change in self awareness occurs as a result of these conferences was not demonstrated; however, the conferences did actively involve the students in planning their learning experience and in taking responsibility for 
meeting their stated objectives.

During the objective setting conferences, several students expressed difficulty in formulating clear and concise learning objectives and that this activity required greater thought than they had expected. A result of holding individual objective setting conferences may not lead to statistically significant greater self awareness, but may in fact, help students become focused with a sense of direction and purpose as discussed by Arner (1979). Individual conferences also may serve to heighten a student's awareness, early in the internship experience, on the importance of working toward fulfilling learning objectives and making adjustments in the early stages to assure, as much as possible, attainment of the learning objectives. By the end of the internship semester, most students indicated on their final evaluation that they had accomplished their learning objectives with $50 \%$ of the interns rating this item as 5 ( $5=$ excellent) and $28 \%$ giving a rating of 4 (4=above expectations). Only one student rated this item as 1 (1=poor).

Students' perception of self on selected variables contained in the Soares student Self Inventory, indicates that students differentiate between success, competence, achievement, confidence and independence. In reviewing selected items from the inventory, an interesting finding was that a high percentage of the students rated themselves 
as very competent and independent but viewed themselves as less than very successful and confident.

RECOMMENDATIONS

Studying how and what we learn from experience provides researchers, practioners and educators a fertile field for inquiry. Such inquiry could result in students having a better understanding of self as a student intern, of what they have learned and how to integrate this knowledge for use in future experiences. The case study method would be appropriate to study the influence of an internship experience on a student's perception of self. The case study method would allow the investigator to look at the many factors that bring a change in perception.

Future research could focus on the learning conversation concept beginning with an objective formulation phase but continuing on an ongoing, scheduled basis with individual students and concluding with a exit conversation after the internship ends. This would allow the student to, as Candy, Harri-Augstein, and Thomas (1985) suggest, talk and process the experience for a deeper understanding. Feedback could also be given to the student regarding final evaluations from the supervisor and faculty advisor.

Review of student journals and asking the student's faculty advisor and site supervisor to complete an inventory on their perception of the student, are additional 
considerations for future research.

Understanding how students view themselves before, during and after an internship and understanding the influences that bring about changes in self perception, could provide important information for students in gaining a better understanding of self to encourage further growth and development. Soares (1980) asserts that our perception of self is in part formed from how we think significant others see us and by the experiences we have. A supervisor recently told of spending an hour or so giving feedback to a student toward the end of the internship. The supervisor reported it became evident to him that the student truly did not have an awareness of how bright and capable she was. He hoped, after their conversation, that she had a better understanding her competency and intelligence.

Investigating how students define success in terms of their self perception could give educators important data on developing strategies and tools for fostering greater awareness of self. It is through the critical engagement of looking at one's self during a learning experience, that greater learning can take place (as discussed by candy, Harri-Augstein, \& Thomas, 1980, Knowles, 1970; and Permaul, 1983). Fostering and encouraging the reflective process of looking at one's self, examining the experience and providing feedback to students should be the desired outcomes of experiential education programs. 
APPENDIX A

Steps for Developing Learning objectives 


\section{STEPS FOR DEVELOPING LEARNING OBJECTIVES*}

\section{DIAGNOSE LEARNING NEEDS}

What are the required competencies for an effective level of performance in your chosen field? Malcolm Knowles describes competency as the ability to do something at some level of proficiency, combining knowledge, understanding, skills, attitudes and values.

\section{SPECIFY LEARNING OBJECTIVES}

Objectives should describe what you will learn, not what you will do to learn them from the internship. Develop objectives that are meaningful to you. Try to use concise, measurable words such as:

$\begin{array}{llll}\text { identify } & \text { apply } & \text { solve } & \text { write } \\ \text { improve } & \text { classify } & \text { select } & \text { relate } \\ \text { define } & \text { explain } & \text { summarize } & \text { contrasts } \\ \text { initiate } & \text { modify } & \text { develop } & \text { counsel }\end{array}$

3. SPECIFY LEARNING RESOURCES AND STRATEGIES

Identify resources you plan to use within and outside the agency. Strategies describe how you plan to accomplish your objectives. Possible words to use in developing strategies could include:

$\begin{array}{llll}\text { observe } & \text { examine } & \text { review } & \text { act } \\ \text { develop } & \text { ask } & \text { assess } & \text { read }\end{array}$

\section{EVIDENCE OF ACCOMPLISHMENT}

Identify areas that will help you determine whether you have learned what you set out to learn.

understanding knowledge skill acquistion

*based on Using Learning Contracts, Malcolm Knowles, 1986 and The Experienced Hand, Tim Stanton and Kamil Ali, 1982 . 


\section{APPENDIX B}

Worksheet for Developing Learning objectives 


\section{WORKSHEET FOR DEVELOPING LEARNING OBJECTIVES}

\section{OBJECTIVES :}

1 .

2 .

3.

4.

5 .

6.

LEARNING ACTIVITIES AND STRATEGIES:

EVALUATION : 
APPENDIX C

Examples of Completed Learning objective sheet 


\section{LEARNING NEED}

Lack of understand of the Rhode Island judicial system.

\section{LEARNING OBJECTIVE}

Develop an understanding of the judicial system, particularly at the superior and District court level.

\section{LEARNING STRATEGY \& RESOURCES}

Observe court proceedings at Superior \& District court. Shadow attorneys whenever possible on cases. Interview a Superior or District Court judge.

Ask questions when unsure about legal terminology.

\section{EVIDENCE OF ACCOMPLISHMENT}

The ability to define legal terminology.

Articulate the judicial process in Superior \& District Court.

Write a paper for faculty advisor comparing and contrasting the court processes.

\section{EXAMPLE \# 2}

\section{LEARNING NEED}

Lack of assertiveness in getting needs met.

\section{LEARNING OBJECTIVE}

Ask questions of supervisor when I am unsure of assignment.

\section{LEARNING STRATEGY AND RESOURCES}

Attend assertive workshop; ask for weekly meetings with supervisor.

\section{EVIDENCE OF ACCOMPLISHMENT}

Number of overtures to supervisor. 


\section{BIBLIOGRAPHY}

Anderson, J., Hughes, L., \& Permaul, J.S. (1984), Research agenda for experiential education in the 80's. Panel Resource Paper No. 14). Raleigh. NC: National Society for Internships and Experiential Education.

Arner, T.D., Arner, C.A., Hawkins, T.L., Peterson, W.D., \& Spooner, S.E. (1979). Student personnel education: A process-outcome model. In college student development revisited: Programs, issues and practices. (pp. 357-364). Falls Church, VA: American Personnel and Guidance Association.

Borzak. L. (Ed.) (1981) Field study: A sourcebook for experiential learning. Beverly Hills, CA: Sage Publications.

Boud, D., Keogh, R. \& Walker, D. (Eds). (1985). Reflection: Turning experience into learning. New York: Nichols Publishing.

Cell, E. (1984). Learning to learn from experience. Albany, NY: State University of New York Press.

Candy, P., Harri-Augstein, S. \& Thomas, L. (1985) Reflection and the self-organized learner: A model of learning conversations. In D. Boud, R. Keogh \& D. Walker (Eds), Reflection: Turning experience into learning (pp.100-116). New York: Nichols Publishing.

Cone, R. (1985). Higher education potential. Experiential Education, 10 (2), 7 .

Dewey, J. (1938). Experience \& education. (1963 ed.) New York: Collier Books.

Duley, J.S. (1982). Learning outcomes: The measurement and evaluation of experiential learning. (Panel Resource Paper No. 6). Raleigh, NC: National Society for Internships and Experiential Education. 
Gazda, G., Asbury, F.R., Balzer, F.J., Childers, W.C., \& Walters, R.P. (1977). Human relations development

(2nd ed.). Boston, MA: Allyn and Bacon, Inc.

Griffin, V.R. (1983). Self-directed adult learners and learning. (Panel Resource Paper No. 13). Raleigh, NC: National Society for Internships and Experiential Education.

Knowles, M.S. (1976). The modern practice of adult education. New York: Association Press.

Knowles, M.S. (1986). Using learning contracts. San Francisco, CA: Jossey-Bass.

Knowles, M.S. \& Associates. (Eds). (1984). Andragogy in action. San Francisco, CA: Jossey-Bass.

Kolb, D.A. (1984). Experiential learning. Englewood Cliffs, NJ: Prentice-Hall, Inc.

Loacker, G., \& Doherty, A. (1984). Self-directed undergraduate study. In M.S. Knowles (Ed), Andragogy in action (pp. 101-119). Washington, D.C.: JosseyBass.

Mccarthy, P., \& Schmeck, R. R. (1988). Students' self concepts and the quality of learning in public schools and universities. In R. R. Schmeck, Learning strategies and learning styles (pp. 131-153). New York: Plenum Press.

Mentkowski, M., \& Doherty, A. (1983). Careering after college: Establishing the validity of abilities learned in college for later careering and professional performance. Milwaukee, WI: Alverno College. (ERIC Document Reproduction Service No. ED $239556)$.

Moore, D.T. (1984). Research on experiential education: A comment on the state of the art. Experiential Education 9 ( 3 ), 1 \& 7 .

National Association of Social Work. (1987). Encyclopedia of social work (18th ed.). Silver Spring, MD: Author. 
Permaul, J.S. (1983). Monitoring and supporting experiential learning. (Panel Resource Paper No. 5). Raleigh, NC: National Society for Internships and Experiential Education.

Riggs, J.M. (1985). Self-percention inventory. Review No.1101, in Mitchell, J.V. (Ed.) The ninth mental measurements yearbook. the University of Nebraska Press, 1350-1351.

Ross, D.D. (1989). First steps in developing a reflective approach. Journal of Teacher Education, 40, (2) 22-30.

Schmeck, R. R., (Ed.). (1988). Learning strategies and learning styles. New York: Plenum Press.

Schon, D. (1987). Educating the reflective practitioner. San Francisco: CA: Jossey-Bass.

Smith, R.M. ( 1982 ). Learning how to learn. Cambridge, MA: The Adult Education Company.

Smyth, J. (1989). Developing and sustaining critical reflection in teacher education. Journal of Teacher Education. 40 (2) 2- 9 .

Soares Associates. (1985) The self-perception inventory adult forms test manual (revised edition). Bridgeport, Ct: Author.

Stanton, T. \& Ali, K. ( 1982). The experienced hand: A student manual for making the most of an internship. Cranston, RI: Carroll Press.

Sugarman, I. (1985). Kolb's model of experiential learning: Touchsotone for trainers, students, counselors, and clients. Journal of Counseling and Development, 64_264-267.

University Associates. (1990). The experiential learning cycle. San Diego, CA.

University Year for Action intern handbook. (Revised 1990). Kingston, RI: The University of Rhode Island. 
Whitman, M. \& Erdynast, A. (1982). Applications of developmental theory to the design and conduct of quality of field experience programs: Exercises for educators. (Panel Resource Paper No. 8). Raleigh, NC: National Society for Internships and Experiential Education.

Wood, S. Interpersonal communication in the work environment. Handout from workshop, date unknown. Kingston, RI: University of Rhode Island.

Yelon, S. \& Duley, J. (1978). Efficient evaluation of individual performance in field placement. Guides for the Improvement of Instruction in Higher Education, 14. East Lansing, MI: Michigan State University.

Zastrow, C., \& Kirst-Ashman, K. (1990). Understanding human behavior \& the social environment. (2nd ed.) Chicago, IL: Nelson-Hall. 